\title{
Does crisis affect credit risk in developing countries?
} The case of the Jordanian Market

\author{
Marc Kouzez ${ }^{a}$, Danielle Lecointre-Erickson ${ }^{b}$ \\ a\&b Groupe de recherche angevin en économie et management, GRANEM, UNIV Angers, France, mkouzez@hotmail.com - \\ danielle.lecointre@univ-angers.fr
}

\begin{abstract}
At the core of the crisis marked by its magnitude, credit risk turned to become a powerful catalyst. The objective of this paper is mainly to follow up the evolution of the credit risk at the Jordanian market during the recent economic and financial international crisis. Based on the linear discriminant model Z-Score and KMV structural model, we recognize the increase in the credit risk during the crisis period. On the whole, the confrontation between models highlights the robust correlation between the accounting results of a company and its market value.
\end{abstract}

Keywords: Credit risk, Crisis, Jordanian Market, Z-score model, KMV structural model

JEL codes: E551, G3, C1

\section{INTRODUCTION}

Ever since the 2007 financial and economic crisis, the world economy has gone through a time of crisis characterized by instability. This crisis is exceptionally noteworthy with no other comparably similar crisis since the 1930s. Markets are becoming ever more open and interconnected, and they are being exposed to an increased risk of contagion. At the heart of this financial crisis, credit risk has constituted a powerful catalyst. Credit risk conventionally corresponds to a situation where borrowers are incapable of honoring commitments with their creditors. There are two possible outcomes. Either the company negotiates a modification to its terms of credit (e.g., staggering payments, modifying rates, etc.), or the company is liquidated (Blazy et al., 2013). In addition, it is possible to consider credit risk as being a case where the financial situation of the borrower deteriorates, which then increases the probability of liquidity risk, especially when the market value of the company sharply declines (Kharoubi et al., 2013). For credit institutions, it is essential to control this risk, to ensure it remains in proportions that are sufficiently low to avoid not only losses on their credit portfolios, but also an increase in their cost of equity capital. To achieve this, the bank portfolio must be regularly examined in order to determine if the yield complies with expectations and if the level of risk remains within acceptable limits.

In period of instability, such as the one experienced by many developed countries since 2007, credit risk has become a topic of concern for credit institutions, whose bankruptcies have strangely increased. For researchers, this crisis has revealed questions not only on banking methods that have been adopted for measuring their credit risk, but also on the contagion of the latter (Collins et al., 2016; Jiang et al., 2018; Ters et al., 2018).

Unlike developed countries where financial products are widely used, the development of financial products remains limited in Middle East and North Africa (MENA) countries. Indeed, since the 1990s, the countries of the MENA region have, for the most part, proceeded in opening their economies and in liberalizing their banking system through structural changes, all while adopting international regulation standards and international financial and banking standards. The banking market in Jordan has not been kept away from this development. This market captures our attention insofar as it presents some specificity on a regional scale. Jordan is an extraordinary, Near-East country because it benefits from a political stability that generates economic activity in a region filled with instability. Since the 1990s, Jordan has adopted a policy of liberalization through a series of reforms aimed at improving the performance of its banking and financial https://doi.org/10.30585/icabml-cp.v2i1.218

(C) 2018 the Authors. Production and hosting by Avicenna FZ LLC. on behalf of Dubai Business School, University of Dubai - United Arab Emirates. This is an open access article under the CC BY-NC license. 
system, at attracting capital to ensure the financing of its development and to correct imbalances in its economy (Brack, 2012). This characteristic gives Jordan a degree of strong international openness for economic and financial relations, remarkable on a regional scale. For example, according to the KOF Economic Globalization Index, its level of openness exceeds that of Egypt. Furthermore, its index has exceeded that of the United States since 2001 and has also shown a level similar to that of France these past years (Figure 1).

Figure 1. KOF Globalization index

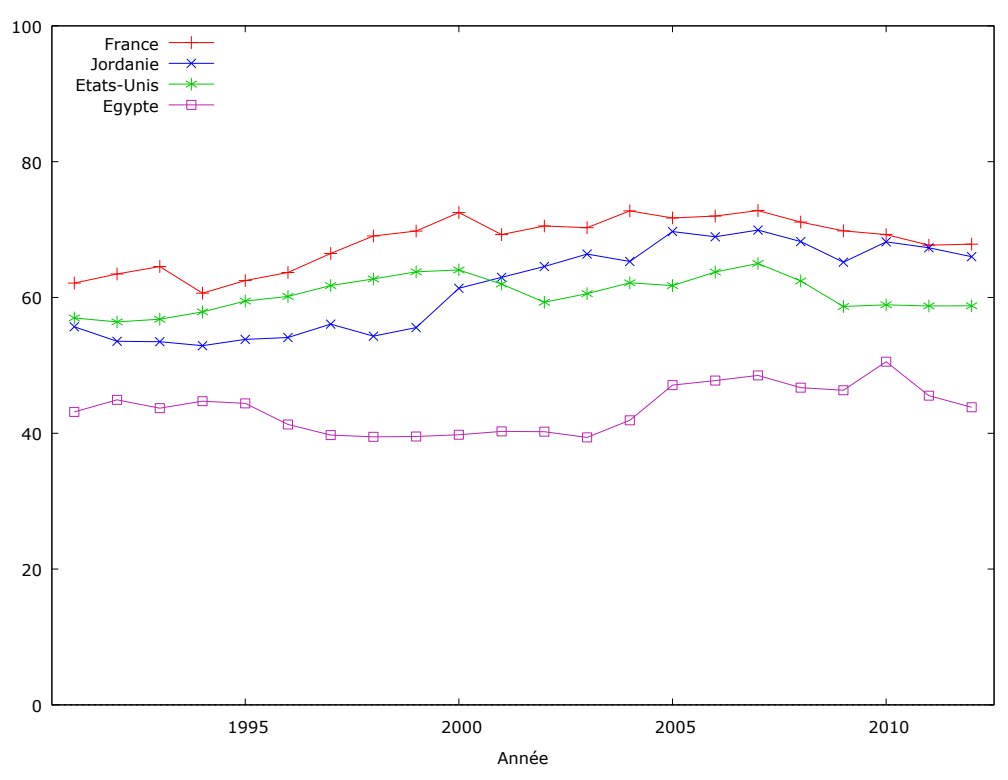

Source: KOF Swiss Economic Institute

At the same time, the regulation of its banking system has been greatly inspired by the prudential standards recommended by the Basel Committee. Moreover, liberalizing the banking system and opening the economy has made Jordan more prone to international crises. The contagion of the American-born crisis to Europe and then to the neighboring countries of the South has clearly had effects that go beyond what was predictable. On the Jordanian market, the outcome of the 2008 crisis was the turnaround of the credit cycle to the private sector (Figure 2). The Jordanian credit market has been marked by an increase from $4.1 \%$ in 2007 to $8.5 \%$ in 2011 in non-performing loans to the balance sheet total (Figure 3). 
Figure 2.

Credit provided to the private sector (\% by GDP)
Figure 3.

Evolution of non-performing loans (\%)

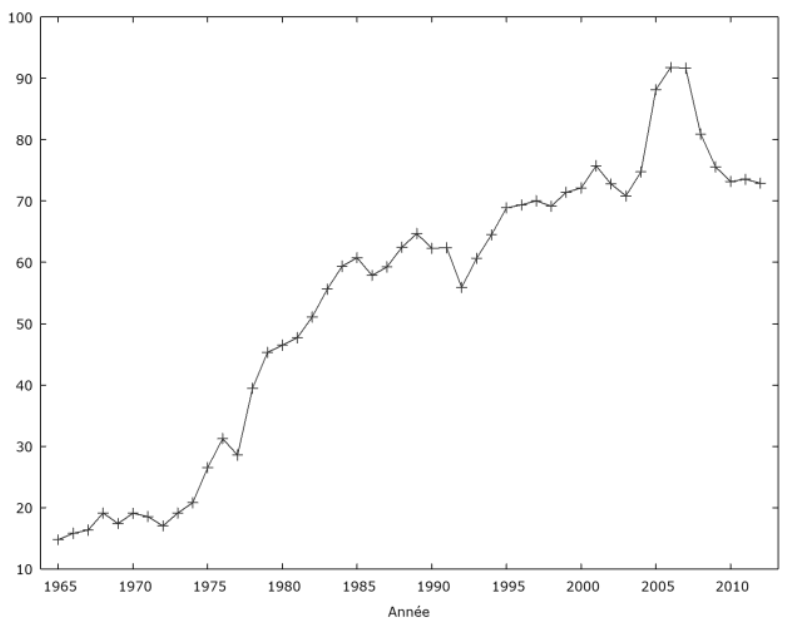

Source: World Bank

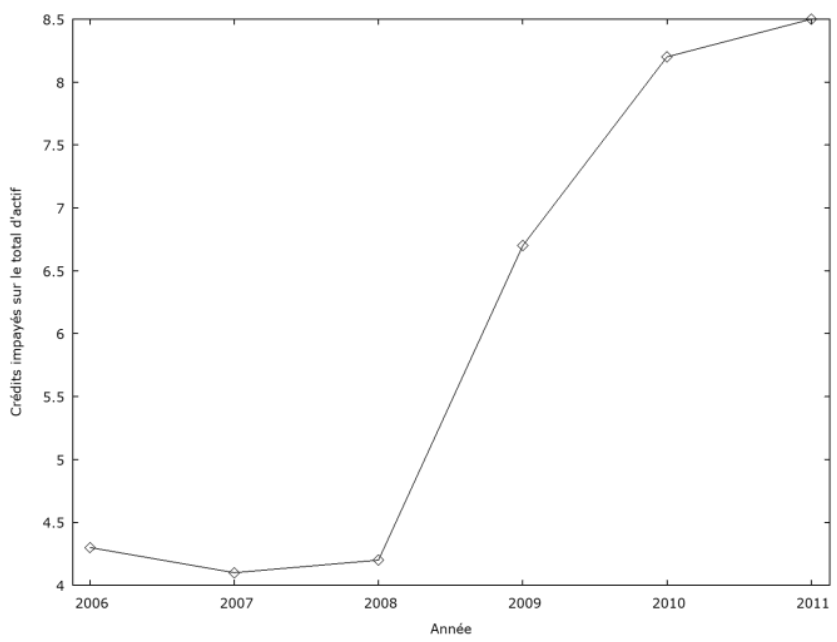

Source: International Monetary Fund

A possible explanation is the decrease in profitability in Jordanian banks: from 15\% in 2006 to $8 \%$ in 2012 (Central Bank of Jordan). At the same time, the market value of Jordanian companies listed on the stock market started to sharply decline beginning in 2007 (Figure 4).

Figure 4. General Market Index (\%)

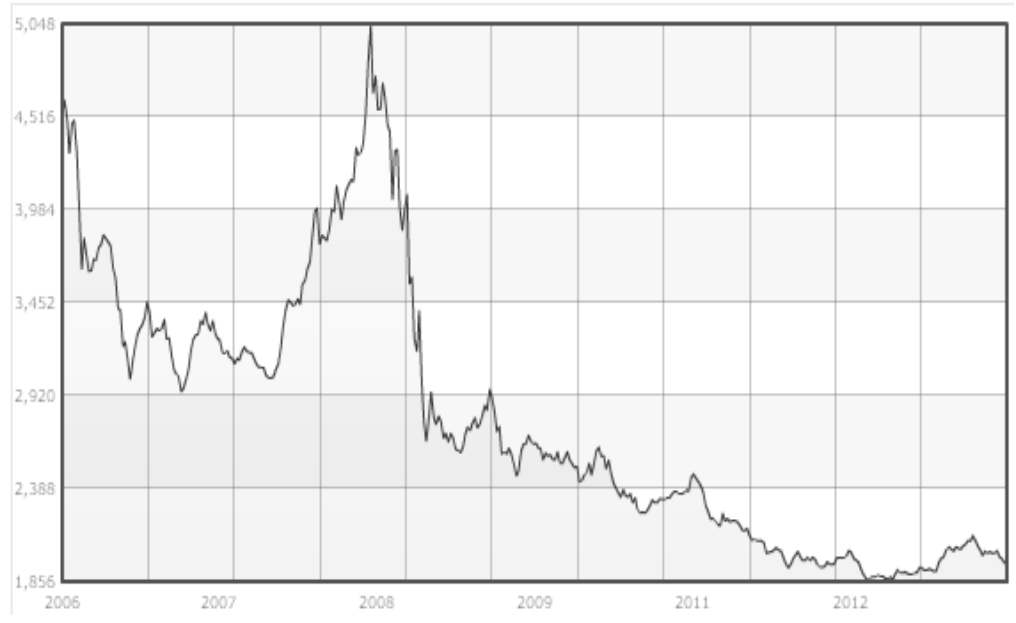

Source: Amman Stock Exchange

Despite the deterioration of Jordanian financial system performance, the banking sector remains very stable. This is illustrated by a Liquidity Coverage Ratio of $159 \%$ and a solvency ratio of $19 \%$, levels which are much greater than those set by Basel Committee standards. Between a remarkable level of stability and deteriorating financial system performance, this paper questions the impact of the policy of openness adopted by the Jordanian banking authorities on the evolution of credit risk, particularly in the recent context of the international crisis. The Jordanian market has not currently received any empirical analysis of its credit risk during the crisis period. To respond to this gap, this paper attempts to contextualize the evolution of the perception of credit risk. In order to illustrate the diversity of measures of risk that credit institutions currently use, this paper then conducts a detailed examination of common approaches to these measures in regards to companies listed on the stock market. The first approach is purely statistical and is founded in the financial business field. Altman's Z-score model is based on accounting data that are unique to each company. The second approach can be qualified as dynamic. It integrates the financial market by taking into consideration the marketbusiness interaction in the assessment of credit risk. This paper illustrates this through the Portfolio Manager model. This type of connection enables an analysis of the indirect effect of the crisis on the Jordanian market through the credit 
risk measured by the two other approaches. The second part of this paper presents the data and the methodology adopted in order to analyze and interpret the results.

\section{LITERATURE REVIEW}

\subsection{Evolution of the perception of credit risk}

Insofar as the core business of banks is to take risks to increase profits, there is obviously great incentive to make such a process more effective. In this context, measuring credit risk represents an intrinsic step in a bank institution's portfolio management. Financial innovations, which are the essential engine of financial change, have undoubtedly enabled the development of methods for measuring credit risk. This evolution has been influenced by several factors: a great increase in the number of bankruptcies worldwide, an increase in financial disintermediation by large companies, a more competitive credit market, the declining value in real assets and collateral, and sharp growth of off-balance sheet instruments (Altman and Saunders, 1998).

Beyond these elements, implementing the Basel II Accord represents a fundamental step in shaping this methodological evolution. This accord has given banks the choice between two principal methods for calculating capital requirements relative to their credit risk. The first method consists in evaluating the risk in line with a so-called "standard" approach by relying on external assessments of credit risk. The second approach is based, for the first time, on adopting an internal rating system conducted by the bank itself, under the condition that the controlling authority gives its explicit approval (Maque et al., 2009). Since then, credit rating models that have been proposed by banks or services firms have become more sophisticated1. These models no longer focus uniquely on individual credit risk. They adopt a portfolio approach integrating the effect of the market into the risk assessment. This approach has been widely adopted, and it is today at the center of the majority of models measuring banks' credit portfolio risk (Gadhoum et al., 2007). Moreover, linear discriminant models based on credit scoring also endure due not only to their simplicity but also to their objectivity. They represent a reference for practitioners and researchers (Li et al., 2010). We now present the linear discriminant approach followed by the structural approach.

\subsubsection{The "Z-Score" linear discriminant approach}

In a linear discriminant approach, failure prediction for a company is determined from accounting data. Thus, a group of variables that are considered by financial analysts as being the most representative of the soundness of a company must be integrated into the model. The objective is that the scoring should be statistically different for the companies that have a risk of failure and the companies that are sound. This allows for a clear distinction between the two categories. It should be noted that the scoring function based on linear discriminant analysis remains the most used method. By studying the contribution of each ratio, the final score that is obtained constitutes the probability that a company will go bankrupt and enables a clear classification.

The founders of this approach are Beaver (1966) and Altman (1968). Beaver's (1966) essential contribution consists in elaborating a unidimensional dichotomous classification allowing to distinguish the failing companies from the companies considered to be sound. Altman (1968) himself relied on a sample of sixty-six companies of which half were sound and the other half were failing. His model attracted particular interest in the sense that he succeeded in isolating $95 \%$ of enterprises one year before failure. Since then, many researchers have adopted the same methodology [Edmister (1972), Altman et Lavallée (1980), Atiya (2001), Grover (2001), Gadhoum et al. (2007), Altman et al. (2013)]. In his seminal model, Altman suggest that it is the profitability, liquidity and solvency ratios that represent the most significant indicators for predicting the failure of a company. The application of his model has led to the emergence of the following optimal scoring function:

$$
Z=1,2 X_{1}+1,4 X_{2}+3,3 X_{3}+0,6 X_{4}+0,99 X_{5}
$$

\footnotetext{
${ }^{1}$ Services firms offer outsourcing solutions for analysing risk, developing existing models or creating new models.
} 
where,

- the $X_{1}$ ratio (Working capital / Total assets): by reporting net liquid assets to total capitalization, the ratio indicates the liquidity of the company.

- the $\mathrm{X}_{2}$ ratio (Retained earnings / Total assets): it measures cumulative profitability over time. Thus, a company that has high reserves can use them to avoid bankruptcy if the company runs into any financial difficulties. Companies that have been recently started will be incapable of making up such reserves, which explains their financial weakness.

- the $X_{3}$ ratio (Earnings before interest and taxes / Total assets): it highlights the productivity of assets, abstracting from fiscal or debt factors. It is obviously a measure of the company's profitability.

- the $\mathrm{X}_{4}$ ratio (Market value equity / Book value of total debt): A company with high debt might become insolvent because of insufficient equity.

- the $\mathrm{X}_{5}$ Capital-turnover ratio (Sales / Total assets): it indicates the generating efficiency of the company's assets.

Altman determines three zones according to the Z-score obtained from the calculation (Figure 5). Companies that have a score equal to or higher than 2.99 are so-called "sound" performing companies that carry a low level of credit risk, whereas all those that obtain a score inferior to 1.81 are companies with a high risk of failure. A score between 1.81 and 2.99 is not sufficient to come to a conclusion; in this "ignorance zone", some companies may be sound whereas others may carry risk.

The descriptive statistical approach is indeed an essential tool for measuring credit risk, where the results are useful not only to credit-policy decision-makers but also to investors and market regulators (Taffler, 1982; Bardos, 1998; Shirata, 1998; Altman et al., 2013). However, this "traditional" model is often qualified by authors as incomplete (see Barth et al., 1998) and needs to be complemented with a supplementary method based on option pricing (Merton, 1974).

Figure 5. Z-Score classification zone

\begin{tabular}{l|c|c}
$\begin{array}{l}\text { Distress Zone } \\
\text { (High Risk of Bankrupt) }\end{array}$ & Grey Zone & Safe Zone \\
$Z<1,81$ & (Uncertain Results) & (Low Risk Area (Healthy) \\
& $1,81<Z<2,99$ & $Z>2,99$ \\
\hline
\end{tabular}

\subsubsection{The KMV "Portfolio Manager" structural approach}

Parametric approaches are based on a theoretical model constructed with precise statistical modeling hypotheses. For banking institutions, these approaches play an increasingly greater role, notably following the implementation of the Basel II accord's first pillar (i.e., capital requirements). Banks can now outsource diverse aspects concerning their rating systems, or even obtain internal risk analysis and management models, such as the one explained above.

As a result, several models have been developed. Examples include the CreditMetrics model proposed by J.P.Morgan's, the Portfolio Manager model proposed by Moody's KMV, the CreditRisk+ model proposed by Crédit Suisse First Boston, and the CreditPortfolioView model proposed by McKinsey. Some models focus on the market value of the firm (e.g., Portfolio Manager and CreditMetrics) and others focus on assessment via the actuarial approach (e.g., CreditRisk+ and CreditPortfolioView).

As its name suggests, the so-called structural approach focuses on the financial structure of the company. It analyzes this structure in the light of financial theory, as an options exchange of the company's value. The use of this approach allows 
for the assessment of the calculated probability of failure of a company so that it is equal to the historical percentage of empirically observed defaults (Gouriéroux and Tiomo, 2007). Our analysis focuses on the approach applied by Moody'sKMV. The Portfolio Manager model originates from the work of Black and Scholes and developed by Merton in 1974. Merton and Scholes rely on the principle that the shares of an indebted company are considered to be call options, with a fiscal level equal to the face value of the debt. In terms of the efficient market hypothesis (Fama, 1970), they show the variation of stock prices of a company must reflect - by public or private information - its financial position and future performance. In line with the structural approach, the default risk thus corresponds to the probability that the market value of assets of a company should be inferior to the value of its bonds (liabilities). The Portfolio Manager model considers credit risk as a dynamic variable and not as a static parameter such as is the case in the Z-score model. In line with this model, credit risk corresponds to the probability of default. It is calculated through the following formula

$$
p_{t}=N\left[-\frac{\ln \frac{V_{A}}{X_{t}}+\left(\mu-\frac{\sigma_{A}^{2}}{2}\right) t}{\sigma_{A} \sqrt{t}}\right]
$$

where,

$N(-)$ : normal distribution

$\mathrm{V}_{\mathrm{A}}$ : market value of assets of firm $\mathrm{A}$

$X_{t}$ : book value of the firm's liabilities payable on date $t$

$\sigma_{\mathrm{A}}$ : the firm's asset volatility

$\mu$ : expected return on assets of the firm².

According to the KMV model, market risk and credit risk are inseparable. In other terms, the increase in market risk - for example, due to the unexpected decrease in the company's value - imply an increase of credit risk and vice versa (Jarrow, 2000). The dynamics of the firm's value allows to characterize the distance to default given by the number of standard deviations separating the asset value of the firm from the default point ${ }^{2}$. The latter corresponds to the critical asset value of the firm below which the company is failing, because the company can no longer satisfy its current debt obligations. In other words, the measure of the asset value of the firm will allow for the calculation of a default distance, presented as the distance between the expected value of assets at a set horizon (e.g., one year) and the default point. This distance to default represents a risk indicator that is then retranscribed in terms of default probability $\left(P_{t}\right)($ Figure 6). The asset value of the firm, its risk of activity, and its financial leverage are thus at the heart of the KMV structural approach (Gatfaoui, 2008).

It is possible to formulate all of the critiques against the Moody's KMV model that are traditionally reproached against the Black and Scholes model, which relies on Brownian motion. In this respect, the continuity of the trajectory of asset value of the company means that we know at any given moment how much these assets are worth and implies that the default event occurs continuously without surprise. Thus, one can say that the default risk has become predictable. On the other hand, this would not be true if switching processes were presented in the modeling of the trajectory of asset value (Kharoubi and Thomas, 2013).

Also, the tools allowing to reduce asymmetry of information that is prevalent among shareholders and creditors are not taken into consideration in the Moody's KMV model. This does not integrate the impact of the signal effect of external rating changes, which thus makes the moment of default totally opaque.

\footnotetext{
${ }^{2}$ This model assumes that the returns on assets are normally distributed.
} 
Figure 6. KMV Model's - Illustration for Default

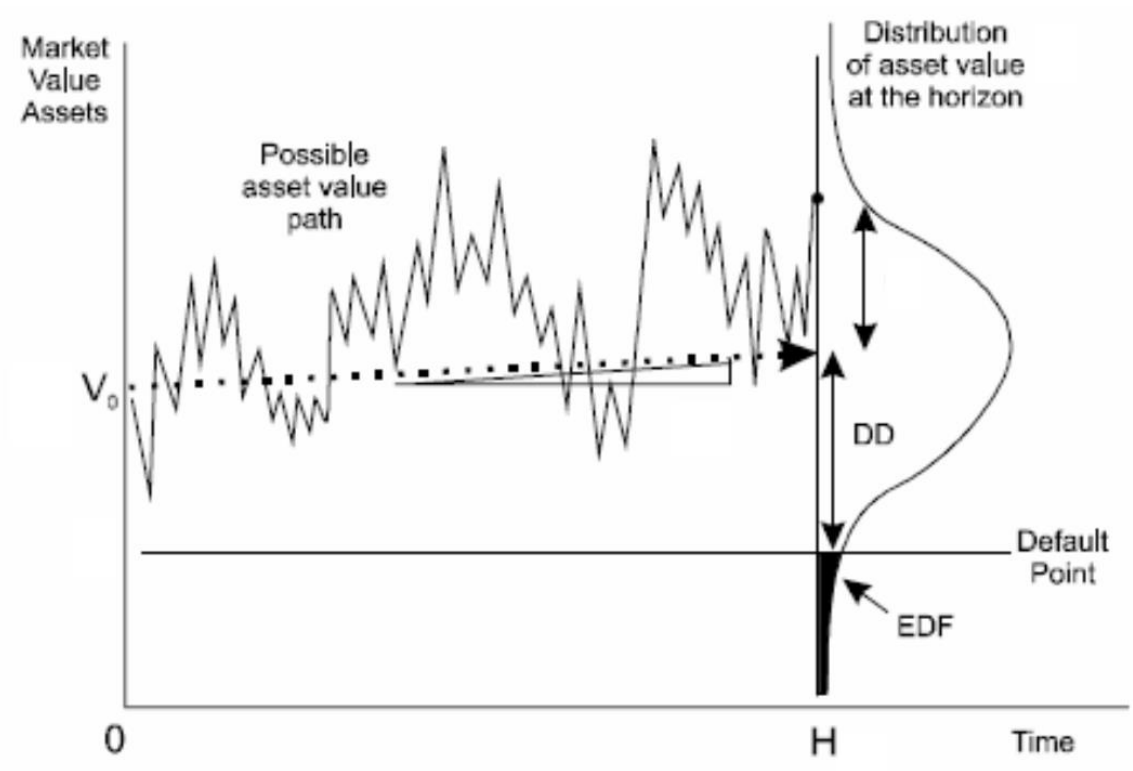

Source : Crosbie and Bohn (2003)

\section{METHODS}

\subsection{Comparative study of Z-Score and KMV models}

\subsubsection{Sampling}

Our sample includes Jordanian companies in the industrial and services sectors listed on the stock market ${ }^{3}$. The period studied extends from 2006 - year preceding the beginning of the crisis - to 2011. The data necessary for the study are annual (i.e., end of the fiscal year). They are pulled from the database for the Jordanian stock market (ASE) ${ }^{3}$. Furthermore, it should be noted that the information on the companies that became bankrupt during this period is not accessible. In line with the rating established by the ASE, the sample includes 99 companies, of which 41 are in the services sector and 58 are in the industrial sector ${ }^{4}$.

\section{ANALYSIS AND RESULTS}

Graphs 1 and 2 represent a summary of the results produced by applying the Z-Score model on our sample. The procedure consists in proceeding with an annual Z-Score evaluation of the 99 companies over the six-year period studied. We distinguish three zones : the default zone (high credit risk), the ignorance zone and the low-risk zone (sound).

In the services sector, we notice from one year to the next a decrease in the number of companies considered to be "sound" starting from 2008 (graph 1). This decrease is sensitive since, between the high point in 2007 and the latest observation (2011), the percentage of sound companies drops from $68 \%$ to $37 \%$. The adverse effect is an increase in the number of companies having a high default risk, which rises from 15\% in 2007 to 39\% in 2011 among all of the companies in the services sector, as well as a more moderate but regular progression of companies in an undetermined situation.

\footnotetext{
${ }^{3}$ The data for private companies not listed on the stock market are unavailable.

${ }^{4}$ Given its specificity, the banking and financial sector were not retained in our analysis.
} 
Graphs 1 and 2. Rating of listed companies with the Z-Score model

Graph 1

Services sector (\%)

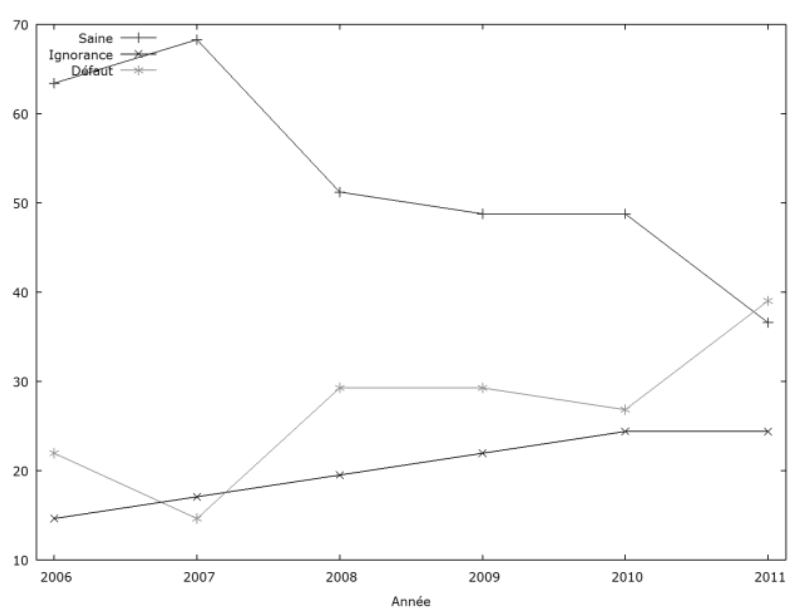

Graph 2

Industrial sector (\%)

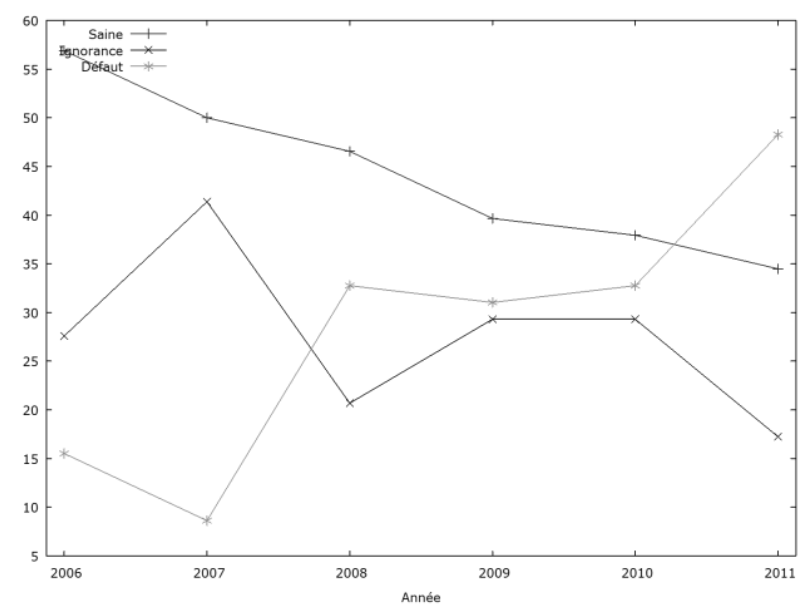

Source : Calculations by the author

The industrial sector, which was already more exposed in 2006, is even more hit by the negative effects of the crisis since 2007 (graph 2). If it is the first year, this translates into a sharp increase in the proportion of companies in an undetermined situation. Starting in 2008, the main adverse effect of the uninterrupted fall of the number of sound companies is the distinct increase of companies that could go bankrupt. In 2011, their proportion greatly surpassed that of sound companies ( $48 \%$ versus $34 \%$ ). The result is more pronounced than in the services sector since the number of companies in an undetermined position does not increase over the global period.

By grouping the results from both sectors (graph 3), we illustrate a clear global increase in credit risk of listed companies starting from 2007, in line with Altman's linear discriminant model. In total, the number of companies with a default risk increased around 144\% from 2007 to 2011.

In parallel, we calculate the annual credit risk of the same companies with the Portfolio Manager structural model. In line with Elhadj ahmed et al. (2011), we consider the default point to be equal to the book value of short-term liabilities increased by half of the long-term liabilities. The application of this approach confirms the increasing evolution of credit risk during these past years in both sectors (graphs 4 and 5).

Graph 3. Rating of listed companies with the Z-Score model (grouped data)

\section{Services and industry sectors}

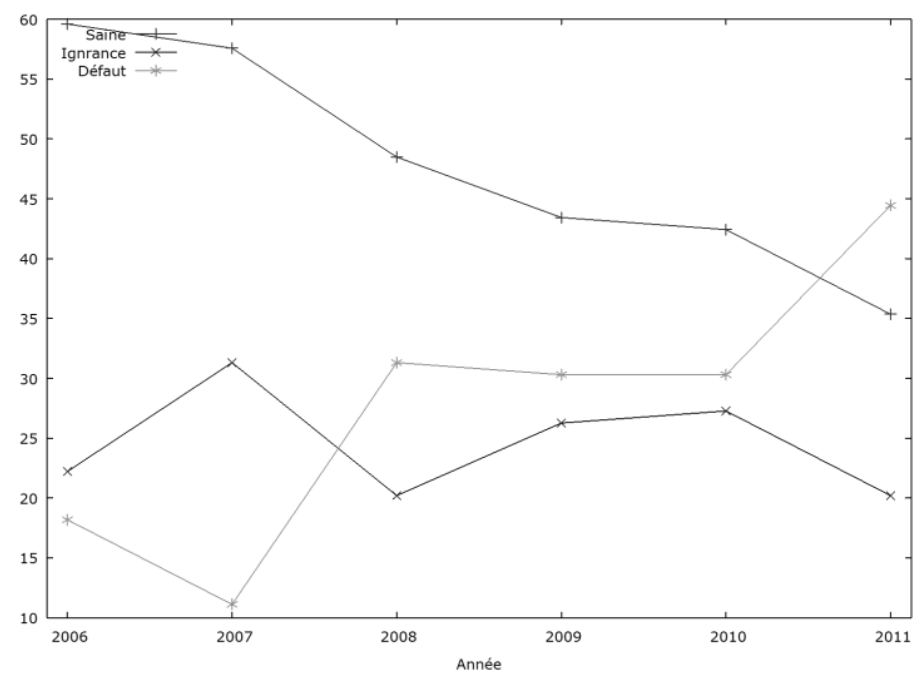

Source : Calculations by the author 
Moreover, in comparison of both methods, the curves representing the results obtained from the structural approach and the Z-Score discriminant analysis show an almost identical evolution, be it the services sector or the industry sector.

Graphs 4 and 5. Evolution of credit risk with the Portfolio Manager and Z-Score models

\section{Graph 4}

\section{Services sector}

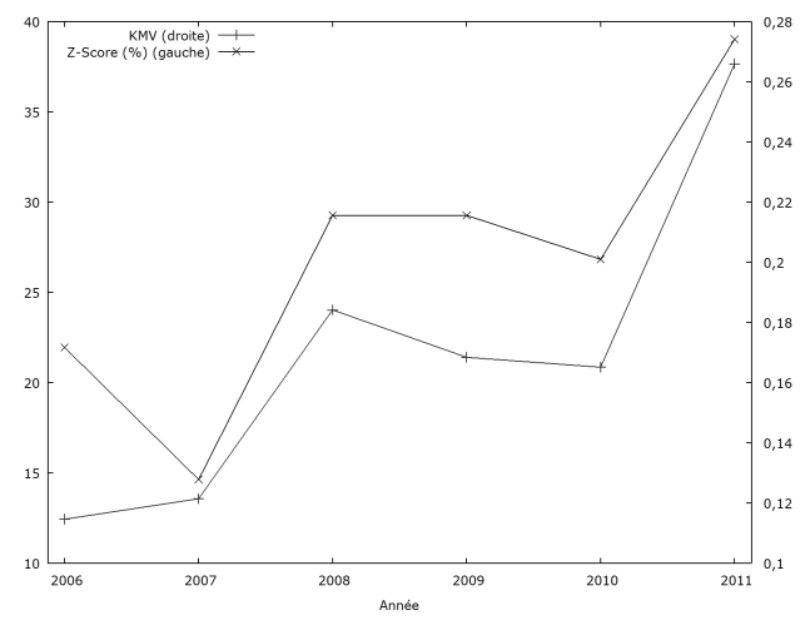

\section{Graph 5}

Industry sector

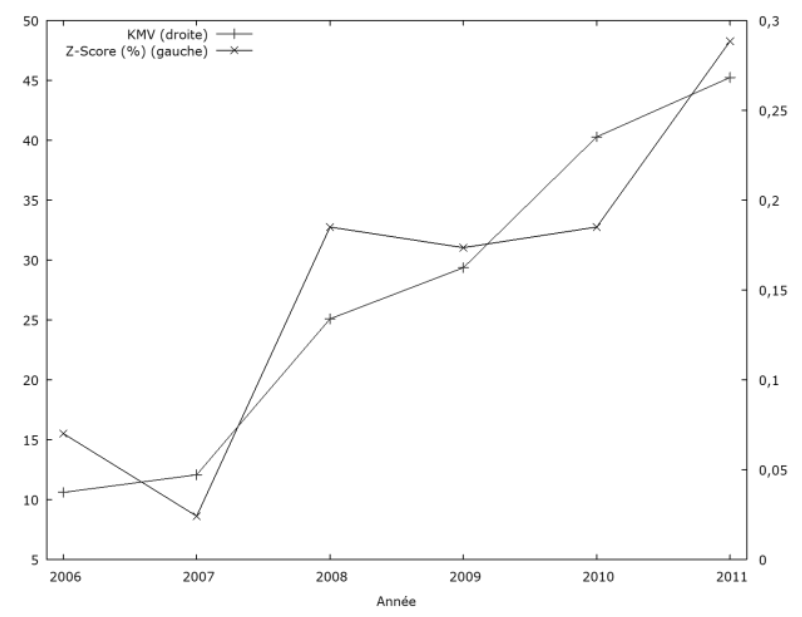

Source : Calculations by the author

Finally, graph 6 which presents a summary of the results from the two grouped sectors obtained from Moody's-KMV Portfolio Manager structural model and Altman's linear discriminant model confirms the previous results.

Graph 6. Evolution of credit risk of listed companies (group data)

\section{Services and industry sectors}

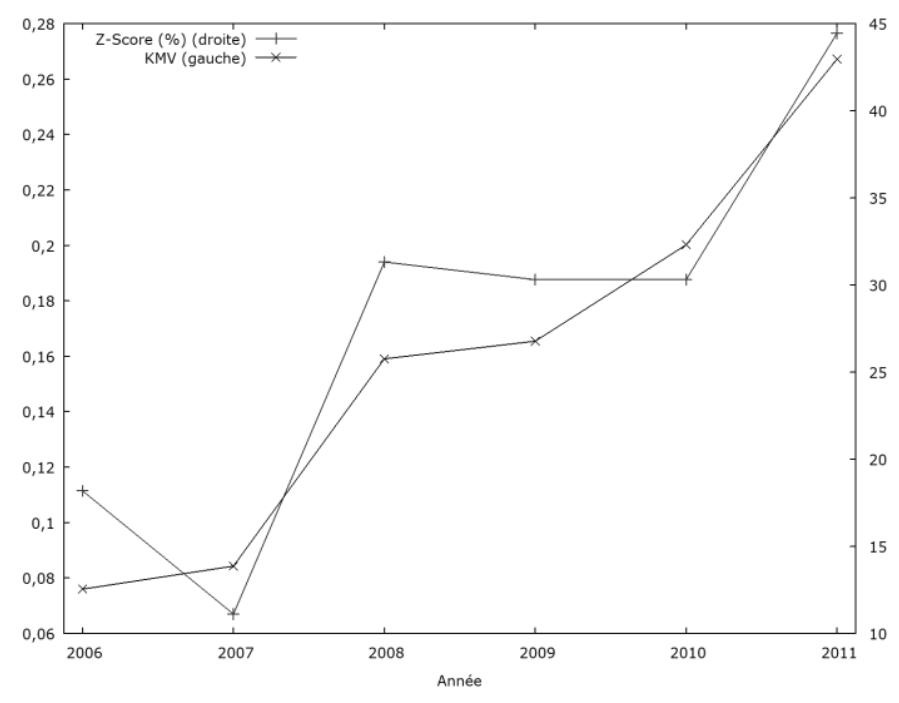

Source : Calculations by the author

The analysis of these estimations show that the deterioration of the performance of companies does not depend solely on the company's financial structure and global performance, but also on its market value. 
Through the book information of Jordanian companies, we provided information on the default rate observed in our sample through Altman's Z-Score and then compared with the probability of default based on market value via the structural model.

Obviously, such a correspondence analysis only makes sense if both scales used make reference to a similar temporal horizon. After taking this element into account, the comparative analysis shows that both curves (Portfolio Manager and Z-Score) follow a close trend with slight gaps throughout the period of analysis (graphs 4, 5, and 6). In other words, the variations in these companies' performance through the book analysis go hand in hand with the change in their stock market value during the period studied ${ }^{5}$.

Following the outbreak of the 2007-2008 economic and financial crisis, the increase of credit risk explains the weakening of banking institutions in Jordan in view of the deterioration of their credit portfolio. This translates, on the one hand, into an increase of outstanding loans on the bank market (Figure 3) and, on the other hand, into a drop in banks' incomes in the period of analysis. Moreover, the increase in credit risk has prompted banks to constrain their loan agreements, which explains the turnaround of the credit cycle to the private sector (Figure 2).

In line with these results, we observed a general increase in credit risk, be it through accounting results or the stock market value of the companies studied. In this analysis, we can confirm a certain transparency in terms of information between the economic agents.

\section{CONCLUSION}

The assessment of credit risk, cyclical monitoring and the preventative and curative handling of unsecured loans are the keywords for a strategy seeking security and performance of a credit portfolio. Moreover, the management of credit risk has never been as important as in the past two decades because of the succession of crises (e.g., the Asian crisis in 1997, the Russian crisis in 1998, the Subprimes crisis in 2007, etc.) on one hand, and financial globalization encouraging phenomena of contagion.

Since the 1990s, Jordan has opted for political liberalization of its banking and financial system. As a result, the banking sector has witnessed a great opening and strong development, but it has also become more sensitive to exterior shocks. Clearly, the economic crisis of the country has become more dependent on external economic and financial flows. Large, non-financial listed companies have not escaped this movement, making banks' credit portfolios sensitive to the international opening of their clients. Since then, in an economic context deteriorated by the economic and financial crisis starting in 2007, it is interesting to observe the repercussions for the banking system, not through international interbank debt, but simply through the standard management framework in the domestic economy. Thus, even though Jordan appears far the origin of the American-born crisis, our study shows the increase of the credit risk of listed Jordanian companies during the financial and economic crisis, both through using Altman's linear discriminant approach and integrating stock market value, as illustrated through the KMV-type structural model.

\section{REFERENCES}

ALTMAN E. (1968) Financial Ratios, Discriminant Analysis and the Prediction of Corporate Bankruptcy, Journal of Finance, vol. 23, Issue 4, 189-209.

ALTMAN E., FALINI A., DANOVI A. (2013) Z-Score Models' application to Italian companies subject to extraordinary administration, BANCARIA, vol. 04, pages 24-37.

ALTMAN E., LAVALLEE M.Y. (1980) Business Failure Classification in Canada, Journal of Business Administration, vol. 12, 147 -162.

ALTMAN E., SAUNDERS A. (1998) Credit risk measurement: Developments over the last 20 years, Journal of Banking \& Finance, vol. 21, 1721-1742.

ATIYA F., (2001) Bankruptcy Prediction for Credit Risk Using Neural Networks: A Survey and New Results, IEEE Transactions on Neural Networks, vol. 12, N 4, 929-935.

Banques des Règlements Internationaux (2004) Convergence internationale de la mesure et des normes de fonds propres, nouveau dispositif.

BARDOS M., (1998) Detecting the risk of company failure at the Banque of France, Journal of Banking and Finance, vol. 22 (October), $1405-1419$.

\footnotetext{
${ }^{5}$ These results bring light to the question of market efficiency, which is not our research question.
} 
BARTH M., BEAVER W., LANDSMANW. (1998), « Relative Valuation Roles of Equity Book Value and Net Income as a Function of Financial Health", Journal of Accounting and Economics, 25, pp. 1-34.

BEAVER W., (1966) Financial ratios as predictors of failure, Journal of Accounting Research, vol. 4, Issue Empirical Research in Accounting: Selected Studies Pages 71-111.

BLACK B., SCHOLES S. (1973) The Pricing of Options and Corporate Liabilities, Journal of Political Economy, vol. 81, N 3, PP 637-654.

BLAZY R., DEFFAINS B., UMBHAUER G., WEILL L., (2013) Severe or gentle bankruptcy law: Which impact on investing and financing decisions?, Economic Modelling, vol. 34, Pages 129-144.

BRACK E., (2012), Systèmes bancaires et financiers des pays arabes Vers un modèle commun ?, Hramattan, ISBN : 978-2-296-96934-6.

COLLINS S., GALLAGHERAB E., 2016 "Assessing the credit risk of money market funds during the Eurozone crisis”, Journal of Financial Stability, Volume 25, Pages 150-165

CROSBIE P., BOHN J., (2003) Modeling Default Risk- Modeling Methodology, Moody's KMV Company, December.

EDMISTER R., (1972) An Empirical Test of Financial Ratio Analysis for Small Business Failure Prediction, Journal of Financial and Quantitative Analysis, 7, 1477.

ELHADJI A.R., BENAMEUR I., (2011) Credit Risk Evaluation: The Econometric vs the Structural Approach, Bankers, Markets \& Investors, no 114 september- october.

FAMA E., (1970) Efficient Capital Markets: A Review of Theory and Empirical Work, The Journal of Finance, vol. 25, No. 2, p. $383-417$.

GADHOUM Y., GUEYIE J., SIALA M.K., (2007) La décision de crédit : Procédure et comparaison de la performance de quatre modèles de prévision d'insolvabilité, Revue des Sciences de Gestion, n²24-225 pages 177 à 183.

GATFAOUI H., (2008) Une histoire du risque de défaut, Economie \& Gestion Sciences économiques, 188 pages

GROVER J., (2001) Financial Ratios, Discriminant Analysis and the Prediction of Corporate Bankruptcy: A Service Industry Extension of Altman's Z-Score Model of Bankruptcy Prediction, Southern Finance Association.

GOURIEROUX C., TIOMO A., (2007) Economie et Statiques Avancées: Risque de crédit Une approche avancée, Economica, CREF 07-05, P383.

JARROW A. R., TURNBULL S. M., (2000) The intersection of market and credit risk, Journal of Banking \& Finance, vol. 24, 271-299.

JIANG S., HONG FAN H., 2018 "Credit risk contagion coupling with sentiment contagion" Physica A: Statistical Mechanics and its Applications, Volume 512, Pages 186-202

KHAROUBI C., Thomas P., (2013) Analyse du risque de crédit, Banque \& Marchés, Revue Banque Edition, P155.

LI H., SUN J., WU J., (2010) Predicting business failure using classification and regression tree: An empirical comparison with popular classical statistical methods and top classification mining methods, Expert Systems with Applications, vol. 37, Issue 8, Pages 58955904.

MAQUE I., GODOWSKI C., (2009) L'intégration de la dimension qualitative dans l'évaluation du risque de crédit des PME, Revue française de gestion, $\mathrm{n}^{\circ} 191, \mathrm{p} .109-122$.

MERTON R., (1974) On the Pricing of Corporate Debt: The Risk Structure of Interest Rates, The Journal of Finance, vol. 29, n², Pages $449-470$

SERVIGNY D. A., ZELENKO I., (2010) Le risque de crédit face à la crise, Dunod, P320.

SHIRATA C.Y., (1998) Financial Ratios as Predictors of Bankruptcy in Japan: An Empirical Research, in: Proceedings of the second Asian Pacific Interdisciplinary Research in Accounting Conference, Seitin pp.437-445.

TAFFLER R.J., (1982) Forecasting company failure in the UK using discriminant analysis and financial ratio data, Journal of the Royal Statistical Society London, UK, Series A, General, vol. 145(3), 342-358.

TERS K., URBAN J., 2018 "Intraday dynamics of credit risk contagion before and during the euro area sovereign debt crisis: Evidence from central Europe" International Review of Economics \& Finance, Volume 54, March 2018, Pages 123-142 


\section{APPENDICES}

\begin{tabular}{|cccc|}
\hline \multicolumn{4}{|c|}{ Appendix 1 (graph 1) } \\
\hline \multicolumn{4}{|c|}{ Z-Score Services sector } \\
Year & Safe & Grey & Distress \\
2006 & 63,41 & 14,63 & 21,95 \\
2007 & 68,29 & 17,07 & 14,63 \\
2008 & 51,22 & 19,51 & 29,27 \\
2009 & 48,78 & 21,95 & 29,27 \\
2010 & 48,78 & 24,39 & 26,83 \\
2011 & 36,59 & 24,39 & 39,02 \\
\hline
\end{tabular}

\begin{tabular}{|cccc|}
\hline \multicolumn{4}{|c|}{ Appendix 2 (graph 2) } \\
\hline \multicolumn{4}{|c|}{ Z-Score Industrial sector } \\
Year & Safe & Grey & Distress \\
2006 & 0,57 & 0,28 & 0,16 \\
2007 & 0,5 & 0,41 & 0,09 \\
2008 & 0,47 & 0,21 & 0,33 \\
2009 & 0,4 & 0,29 & 0,31 \\
2010 & 0,38 & 0,29 & 0,33 \\
2011 & 0,34 & 0,17 & 0,48 \\
\hline
\end{tabular}

\begin{tabular}{|cccc|}
\hline \multicolumn{5}{|c|}{ Appendix 3 (graph 3) } \\
\hline \multicolumn{4}{|c|}{ Z-Score Grouped data } \\
Year & Safe & Grey & Distress \\
2006 & 0,596 & 0,2222 & 0,1818 \\
2007 & 0,5758 & 0,3131 & 0,1111 \\
2008 & 0,4848 & 0,202 & 0,3131 \\
2009 & 0,4343 & 0,2626 & 0,303 \\
2010 & 0,4242 & 0,2727 & 0,303 \\
2011 & 0,3535 & 0,202 & 0,4444 \\
\hline
\end{tabular}

\begin{tabular}{|cc|}
\hline \multicolumn{2}{|c|}{ Appendix 4 (graph } \\
\hline \multicolumn{2}{|c|}{ KMV Service } \\
Year & CR \\
2006 & 0,1146 \\
2007 & 0,1214 \\
2008 & 0,1842 \\
2009 & 0,1684 \\
2010 & 0,1651 \\
2011 & 0,266 \\
\hline
\end{tabular}

\begin{tabular}{|cc|}
\multicolumn{2}{|c|}{ Appendix 5 (graph 5) } \\
\hline \multicolumn{2}{|c|}{ KMV } \\
Year & CR \\
2006 & 0,0374 \\
2007 & 0,0472 \\
2008 & 0,1339 \\
2009 & 0,1624 \\
2010 & 0,2353 \\
2011 & 0,2683 \\
\hline
\end{tabular}

\begin{tabular}{|cc|}
\hline \multicolumn{2}{|c|}{ Appendix 6 (graph 6) } \\
\hline KMV Services and industrial sector \\
Year & CR KMV Mean \\
2006 & 0,0760 \\
2007 & 0,0843 \\
2008 & 0,1591 \\
2009 & 0,1654 \\
2010 & 0,2002 \\
2011 & 0,2671 \\
\hline
\end{tabular}


https://doi.org/10.30585/icabml-cp.v2i1.218

(C) 2018 the Authors. International Conference On Advances In Business Management And Law 2018 